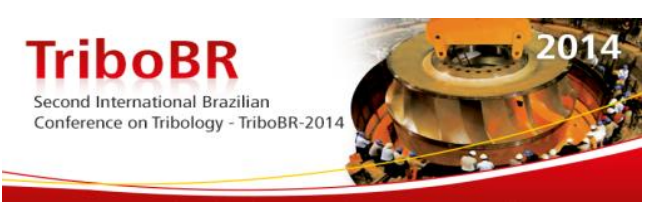

\title{
TRIBOLOGICAL BEHAVIOUR OF DENTAL ENAMEL UNDER RECIPROCATING SLIDING*
}

\author{
Priscilla Pessin Coppo ${ }^{1}$ \\ Mateus Aguiar Martins ${ }^{2}$ \\ Flavio José da Silva ${ }^{3}$ \\ Cherlio Scandian ${ }^{4}$ \\ Rafael Yagüe Ballester 5
}

\begin{abstract}
The prevention of dental enamel wear has particular relevance for preventive and restorative purposes in dentistry. The wear damage can increase due to salivary disorders and/or parafunction (bruxism); antagonists incisal surfaces become flat and coincident. This study aims to investigate the wear behavior and the related mechanisms in sliding pairs of conformal incisal enamel, with similar values of hardness and fracture toughness, with different applied normal loads and lubricated conditions. Bovine incisors, under pin on flat configuration, were tested in two lubrication condition (dry or with natural saliva) and two applied normal loads (8 and $16 \mathrm{~N}$ ). The worn surfaces were investigated by 3D profilometry and SEM. The analysis of worn surfaces indicated mechanisms of brittle fracture, but with different severities. Under a normal load of $16 \mathrm{~N}$ and dry condition, wear is controlled by a brittle process: microcracking with flake-like wear particles, which results in high friction coefficient $(>0.85)$, wear rate and wear volume. On the other hand, under a normal load of $8 \mathrm{~N}$ and natural saliva, wear took place in the interprismatic region, with consequent exposure of prisms and fracture in localized regions. In this case, the friction coefficient was $16 \%$ lower and the wear volume was one order of magnitude lower. Under $8 \mathrm{~N}$ and natural saliva, the wear was greater than in the dry condition, probably due to tribochemical reactions.
\end{abstract}

Keywords: Enamel wear; Pin-on-flat configuration; Normal load; Lubrication condition.

1 D.Sc student, Department of Biomaterials and Oral Biology, USP, São Paulo, São Paulo, Brazil.

Eng. student, Department of Mechanical Engineering, UFES, Vitória, Espírito Santo, Brazil.

3 D.Sc, adjoint professor, Department of Mechanical Engineering, UFPE, Recife, Pernambuco, Brazil.

4 Dr., assistant professor, Department of Mechanical Engineering, UFES, Vitória, Espírito Santo, Brazil.

5 D.Sc, professor, Department of Biomaterials and Oral Biology, USP, São Paulo, São Paulo, Brazil.

* Technical contribution to the $2^{\text {nd }}$ International Brazilian Conference on Tribology - TriboBR 2014, November $3^{\text {rd }}$ to $5^{\text {th }}$, 2014, Foz do Iguaçu, PR, Brazil. 


\section{INTRODUCTION}

Tooth wear is a very common problem, without prevention or treatment protocols established; increases with age, due to the functional use of the teeth, but this is not enough to explain tooth wear found in children and young adults. The wear may be the result of specific factors such as diet, reduced salivary flow or high loads resulting from parafunctional habits of teeth grinding - bruxism [1-4]. For example, the presence of enamel wear was common to all subjects examined among 1010 adults with different ages (18-30 years). The most commonly affected teeth were the incisors, on the incisal surface [5]. The wear of the incisal surfaces, which do not normally come into contact during masticatory movements, can be attributed to parafunctional habits. The shiny/smooth feature of antagonists teeth incisors and canines, as also the coincident incisal surfaces, on regions not involved with masticatory movements are reference signals for the clinical diagnosis of bruxism/parafunctional habits [6].

Although dental enamel is an acellular tissue highly mineralized (microscopic crystals of calcium phosphate apatite represent $99 \%$ of the dry weight) [7] and with high hardness [8], it has a low plastic deformation capability. For these reasons dental enamels are more likely to suffer brittle fracture when subject to the contact stresses. Like ceramic materials, when two teeth slide over each other (wear mode that represents bruxism), the stress distribution is modified and there is a reduction in the normal load necessary to cracks nucleation and propagation [9].

The presence of a lubricant could change the wear regime from severe to mild, although could also induce chemical reactions on surface, which affect wear behavior, as found for ceramic materials [10]. Like these materials, the dental enamel also shows a wear reduction when lubricated by saliva [11]. Wear mode changes caused by different environments could be explained by mechanical properties variations in the enamel surface and/or by chemical reactions induction $[12,13]$. However a little is known about the synergistic effect between saliva and loading on the induction of brittle mechanisms or tribochemical reactions when two incisal surfaces slide over each other.

Due to several buccal environments, different applied loads during parafunctional movements and the constant change in worn surfaces features, laboratorial reproduction of the enamel wear mode in sliding conditions becomes complex. Besides that, mechanical properties related to the enamel wear behavior, as hardness, fracture toughness and elastic modulus, are modified by anisotropy and non-uniform chemical composition in different layer depths and also at the same layer $[7,8,14]$. In this way, to understand the dental wear behavior it is important to characterized dental tissue properties, like hardness and fracture toughness, together with tribosystem parameters, as load, velocity and lubrication.

This work aims to investigate the sliding wear behavior of bovine dental enamel. The sliding wear tests were performed in a pin-on-flat configuration with different applied normal loads in dry and lubricated conditions. Enamel surfaces were mechanically characterized by microhardness and fracture mechanics tests. Wear volume are calculated and micromechanisms evaluated.

* Technical contribution to the $2^{\text {nd }}$ International Brazilian Conference on Tribology - TriboBR 2014, November $3^{\text {rd }}$ to $5^{\text {th }}$, 2014, Foz do Iguaçu, PR, Brazil. 


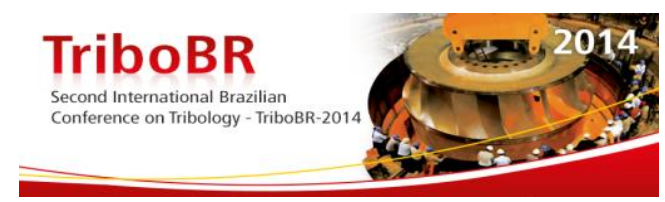

\section{MATERIAL AND METHODS}

\subsection{Specimen Preparation}

Recently extracted bovine teethes were kept in water at $4 \mathrm{C}$ and after were embedded in acrylic resin chemically activated to form 20 sliding pairs, counter-body and body, pin on flat configuration (Figure 1). The specimens were cut in a machine designed for this purpose (Figure 2). It has been demonstrated that the bovine enamel has a microstructure similar to that of human enamel. However, the apatite particle size is $22-23 \mathrm{~nm}$ for bovine and $110-200 \mu \mathrm{m}$ for human $[15,16]$.

(a)
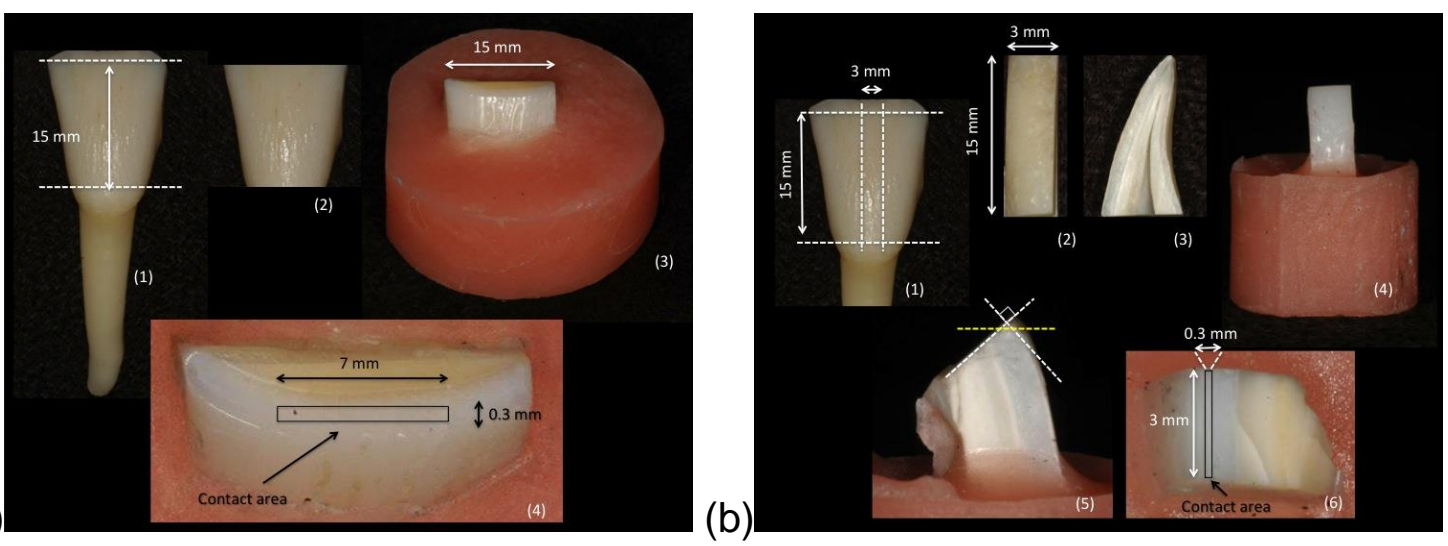

Figure 1. (a) Flat: (1) location of the cuts (dashed lines) for removal of dental root and incisal planning; (2) after the cuts; (3) after embedding in resin; (4) incisal view of the body highlighting the enamel region planned for the area of contact. (b) Pin: (1) location of the cuts; (2) vestibular view and (3) lateral view of the pin after the cuts; (4) after embedding in resin; (5) white dashed lines indicate cutting planes on the buccal and lingual surfaces $\left(90^{\circ}\right)$, yellow dashed line indicates the cut for incisal planning; (6) contact area.

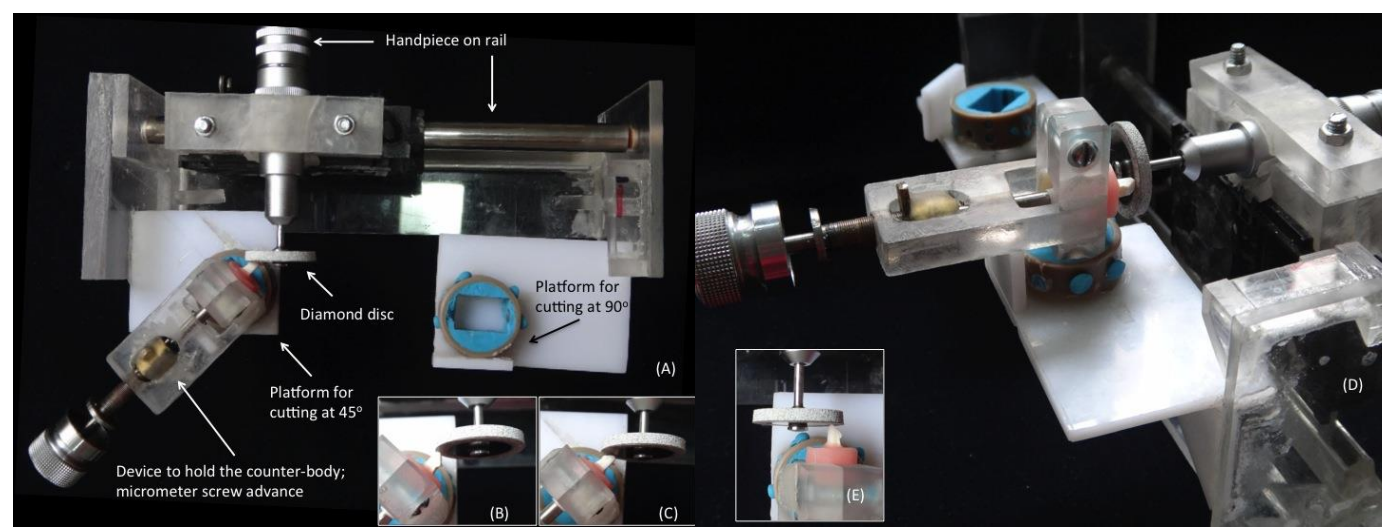

Figure 2. (A) Top view of the machine with the counter-body positioned in support for cuts at $45^{\circ}$ in (B) vestibular and (C) lingual surfaces; (D) lateral view and (E) top view of the machine with the counterbody positioned in support for cut at $90^{\circ}$.

After cutting and embedment, the body and the counter-body are polished down to 1200 grades and alumina suspension $(6,3$ and $1 \mu \mathrm{m})$. The $\mathrm{Sq}$ value was $1.17 \pm 0.05$ $\mu \mathrm{m}$. After polishing, all the samples were stored in distilled water at $4 \mathrm{C}$.

Indentation tests were run on the specimens before reciprocating sliding tests. Six Vickers indentation $\left(\mathrm{HV}_{1,0}\right)$ were made for each specimen (Figure 3). Teeth with microhardness $200 \pm 21 \mathrm{HV}_{1,0}$ were included in this study. The indentation technique evaluated the fracture toughness $\left(\mathrm{K}_{\mathrm{Ic}}\right)$ as well. The $\mathrm{K}_{\mathrm{Ic}}$ value was $1.27 \pm 0.17 \mathrm{MPa} \cdot \mathrm{m}^{1 / 2}$. Similar results have been reported for hardness and fracture toughness values [17-19].

* Technical contribution to the $2^{\text {nd }}$ International Brazilian Conference on Tribology - TriboBR 2014, November $3^{\text {rd }}$ to $5^{\text {th }}$, 2014, Foz do Iguaçu, PR, Brazil. 


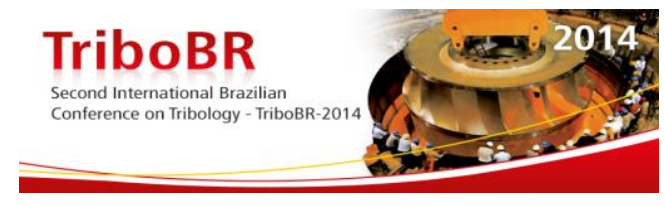

(a)

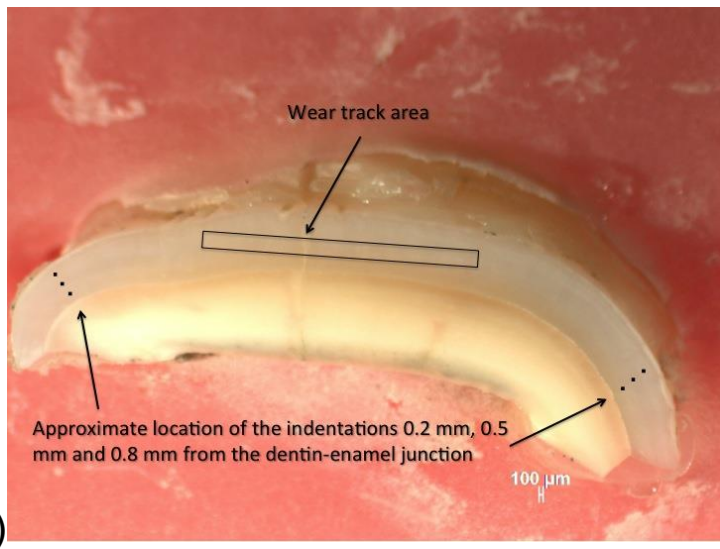
(b)

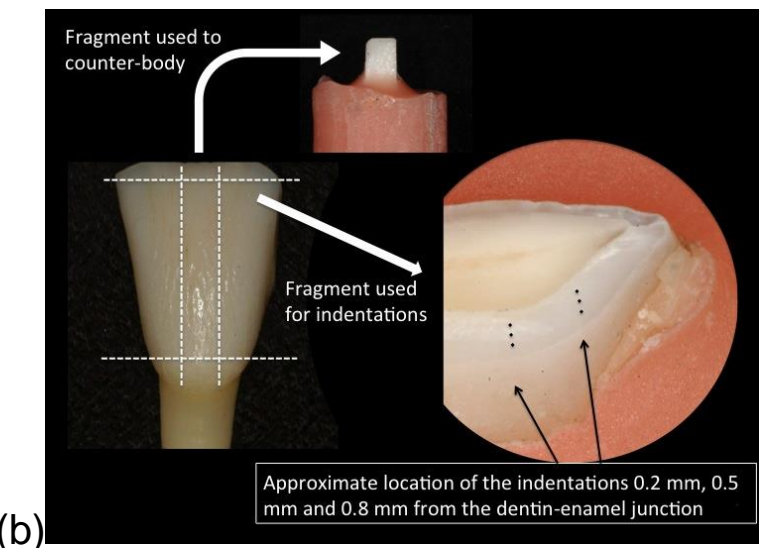

Figure 3. Scheme location of the Vickers indentations in the (a) body and the (b) proximal tooth fragments used to form the counter-body.

\subsection{Lubricant}

The lubricant used in some pairs was natural saliva. Saliva was collected from a single donor, after chewing semitransparent polymer film, odorless, colorless, tasteless and water resistant. The donor was instructed not to eat or drink for 1 hour before saliva collection. The saliva collected in the first minute was discarded. The stimulated saliva was placed in a sterile bottle each 1-minute intervals. They were collected $6 \mathrm{ml}$ of saliva; immediately after collection, $0.5 \mathrm{ml}$ of saliva was deposited on the flat surface of the body with graduated syringe. The donor consented to participate in the study and signed an informed consent.

\subsection{Reciprocating Sliding Tests}

Reciprocating sliding tests are carried out on CETR $^{\circledR}$ tribometer (Figure 4). To avoid individual differences and to assure the repetition of experimental results, five tooth pairs were tested for each condition. The specimens were grouped into four subgroups (5 pairs in each sub-group), according to the normal load and the lubrication condition: $8 \mathrm{~N}$ without lubrication (dry condition); $8 \mathrm{~N}$, natural saliva; $16 \mathrm{~N}$, dry condition; $16 \mathrm{~N}$, natural saliva. The normal load values were estimated from measurements of bite force [20-22]. Of the 5 pairs tested in each condition, 3 tests had duration of $900 \mathrm{~s}$ and 2 tests were interrupted on $40 \mathrm{~s}$. The other test parameters were as follow: sliding speed $2 \mathrm{~mm} / \mathrm{s}$; frequency $0.25 \mathrm{~Hz}$; room temperature. The sliding speed and frequency used in this study were based on clinical observation.

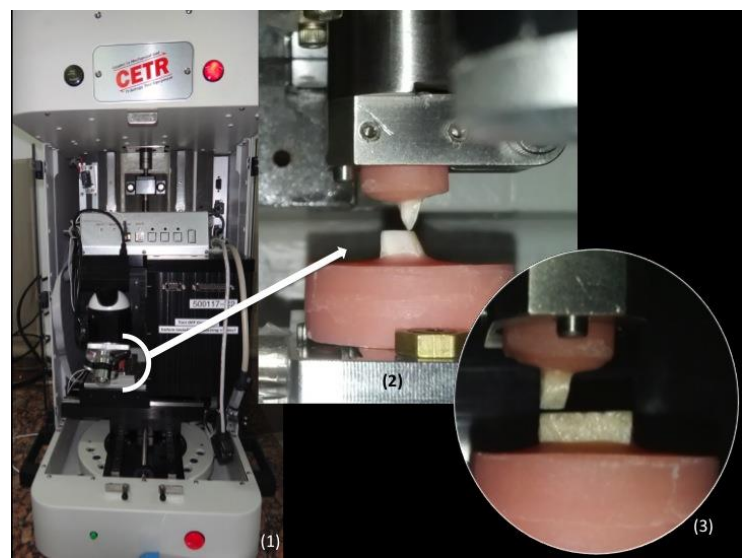

Figure 4. (1) Body and counter-body on the tribometer; (2) lateral view and (3) vestibular view.

* Technical contribution to the $2^{\text {nd }}$ International Brazilian Conference on Tribology - TriboBR 2014, November $3^{\text {rd }}$ to $5^{\text {th }}$, 2014, Foz do Iguaçu, PR, Brazil. 


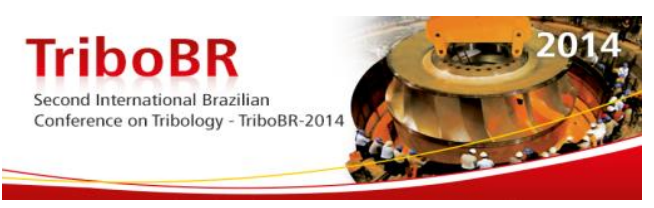

Variations of tangential force vs. reciprocating displacement and coefficient of friction $(\mu)$ were recorded automatically as a function of time. Wear was determined from wear volume. The final wear volume of each condition was decided by the mean of three tests of 900 s.

\subsection{Worn Surfaces Evaluation}

After cleaning by distilled water and ethanol using ultrasound, topographycal analysis was performed in a Taylor Hobson profilometer to verify the wear volume and Sq in the worn surfaces. The worn surfaces were also analyzed in the Scanning Electron Microscopy (SEM).

\section{RESULTS AND DISCUSSION}

\subsection{Wear Behavior - 40s tests}

The early stages of wear process were observed in samples tested during 40 s, with a normal load of $8 \mathrm{~N}$ and in both lubrication conditions, as shown in Figure 5.

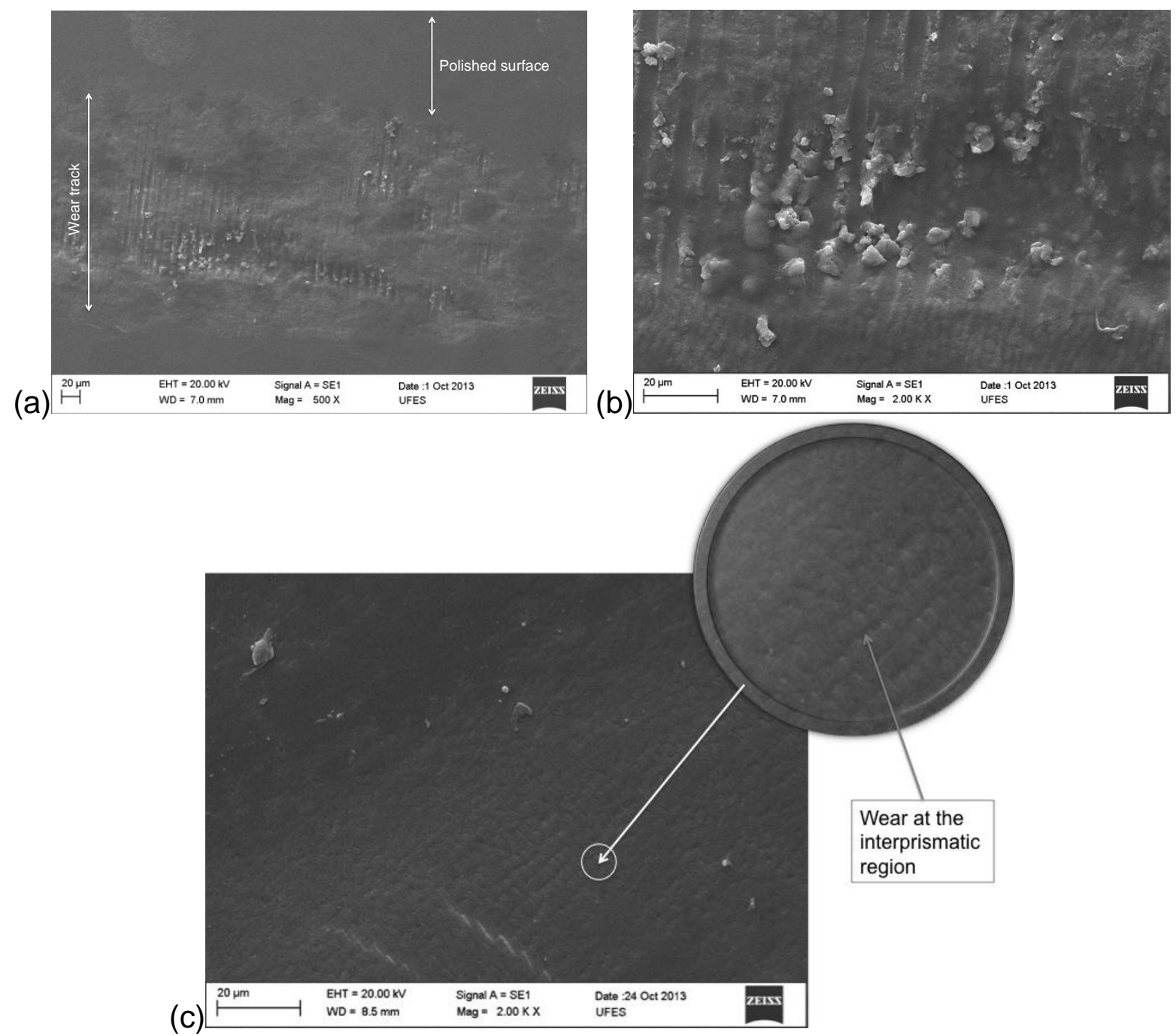

Figure 5. SEM micrographs of flat specimens $(40 \mathrm{~s})$ : (a) $8 \mathrm{~N}$, dry condition and (b) shows a higher magnification SEM image in (a); (c) $8 \mathrm{~N}$, natural saliva.

* Technical contribution to the $2^{\text {nd }}$ International Brazilian Conference on Tribology - TriboBR 2014, November $3^{\text {rd }}$ to $5^{\text {th }}$, 2014, Foz do Iguaçu, PR, Brazil. 
In dry condition, due to compression loads, prisms were separated and the formation of debris occurred, which can be seen in Figure 5 (a) and (b).

In natural saliva condition, the loss of material started at the interprismatic region, wich can be seen in Figure 5 (c) (interrupted test). The initial enamel material loss at the interprismatic region has been reported, but under three-body wear condition [23]. It was reported that, compared to those in the enamel prisms, Young's modulus and hardness were lower in the interprism enamel, which can be due to changes in crystal orientation and the higher content of soft organic tissue in these areas $[7,14]$.

\subsection{Wear Behavior - 900 s tests}

The wear volumes of specimens tested under different conditions are shown in Figure 6 . It could be noted that the wear volume at low load, $8 \mathrm{~N}$, is smaller than that of $16 \mathrm{~N}$, in both lubrication conditions. Under a normal load of $8 \mathrm{~N}$, the presence of natural saliva leads to a higher mass loss (approximately 8 times). This could be explained by the synergistic effect of loading and tribochemical reactions when samples are lubricated with natural saliva. Figure 7 illustrates this behavior: while in 7 (a) there are typical characteristics of mechanical wear, figure 7 (b) it is likely to be a tribochemical wear: a worn smooth surface despite a large amount of lost volume.

On the other hand, under the normal load of $16 \mathrm{~N}$, the mechanical effect is more important than tribochemical reactions, with increased formation of debris due to a brittle wear mechanism, like those presented by ceramic materials; the same was already found by [24]. Shallow cracks parallels to the surface coalesce resulting in debris in the form of micro-plates, a flake-like wear; such mechanism was described for brittle materials [9]. Figure 7 (c) shows a more severe material loss when there was no lubrication by natural saliva, while in Figure 7 (d) the degree of severity is lower. Such brittle mechanism found in dental enamel was named delamination in previous studies $[23,24]$. However, in this work, we used the classic tribological definition $[9,25]$. The presence of natural saliva was beneficial to reduce the wear volume.

Under $8 \mathrm{~N}$ and natural saliva, the wear was greater than the dry condition, which apparently seems to be a clinical oxymoron, but this condition can be compared to that found in vivo: individuals without apparent changes in salivary flow show considerable wear with coverage loss of dental enamel and dentin exposure, even when young, in age from 18-25 years [5]. This predominant mode of wear seems to be coming from sliding under high loads (bruxism) because the enamel wear occurs on surfaces that do not come into contact during masticatory movements, or functional movements; only during parafunctional movements. However, the determination of a single mode in the oral environment is difficult because abrasion, sliding and/or corrosion wear occur simultaneously during the day.

Clinical characteristics in vivo of wear lesions from bruxism, such that regular and shiny surfaces [6], seems to be another important indicator correlated with the presence of tribochemical reactions. Unlike the rough and dull feature of the wear track of the samples tested in the dry condition (Figure 8 (a)), the surface of the samples tested with natural saliva showed more regular and bright macroscopic appearance (Figure 8 (b)); similar to the clinical aspect found in wear lesions. The need of chemical interactions to form regular and shiny surfaces interaction was also observed in the groups in which there was synergy between mechanical loading and reaction with the medium (citric acid with $\mathrm{pH} 3.2$ ) [12].

* Technical contribution to the $2^{\text {nd }}$ International Brazilian Conference on Tribology - TriboBR 2014, November $3^{\text {rd }}$ to $5^{\text {th }}$, 2014, Foz do Iguaçu, PR, Brazil. 

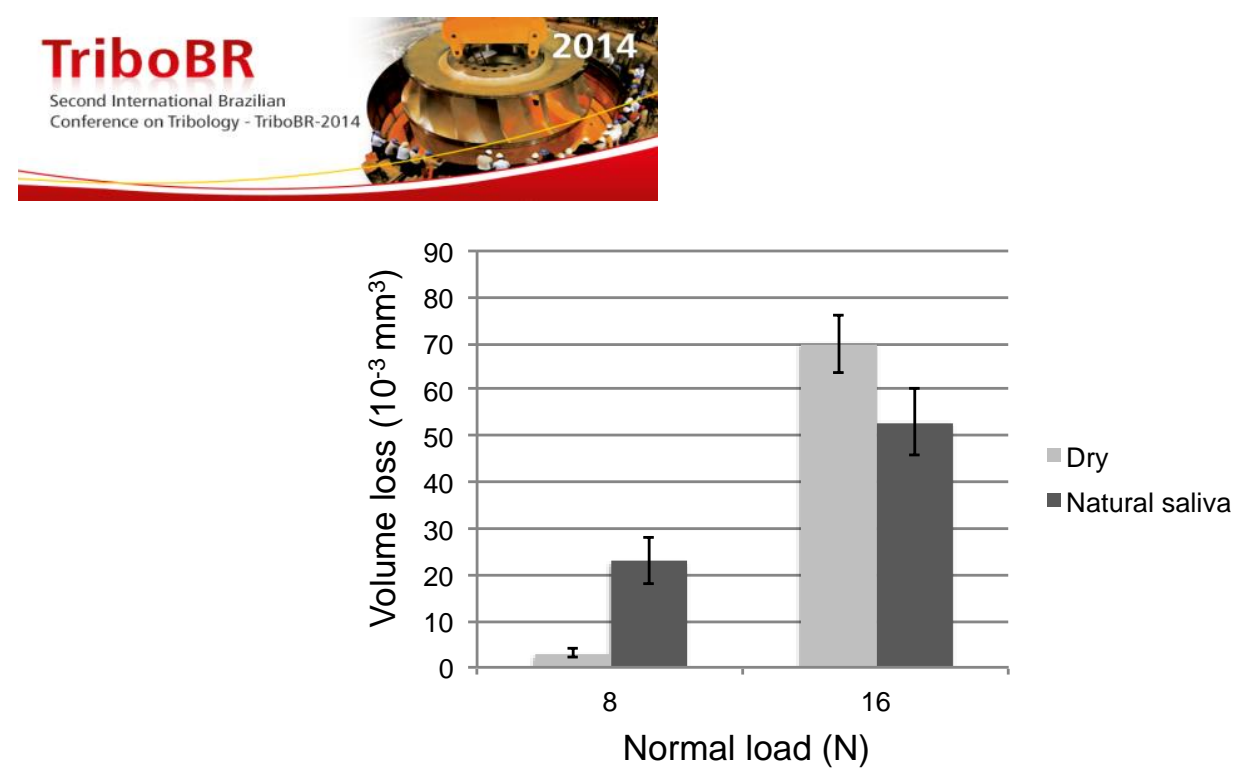

Figure 6. Mean wear volume of the tested specimens in different lubrication conditions as a function of normal load.

(a)

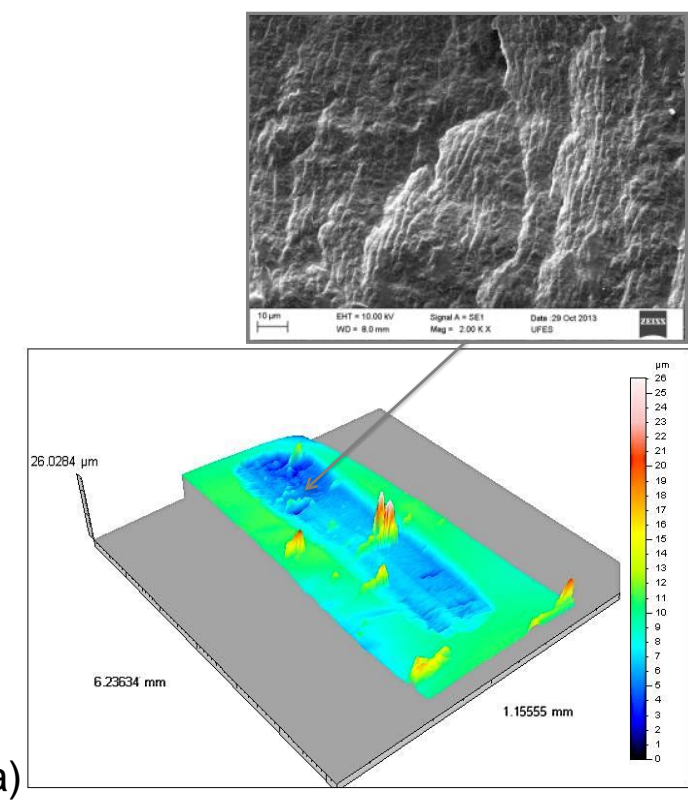

(b)
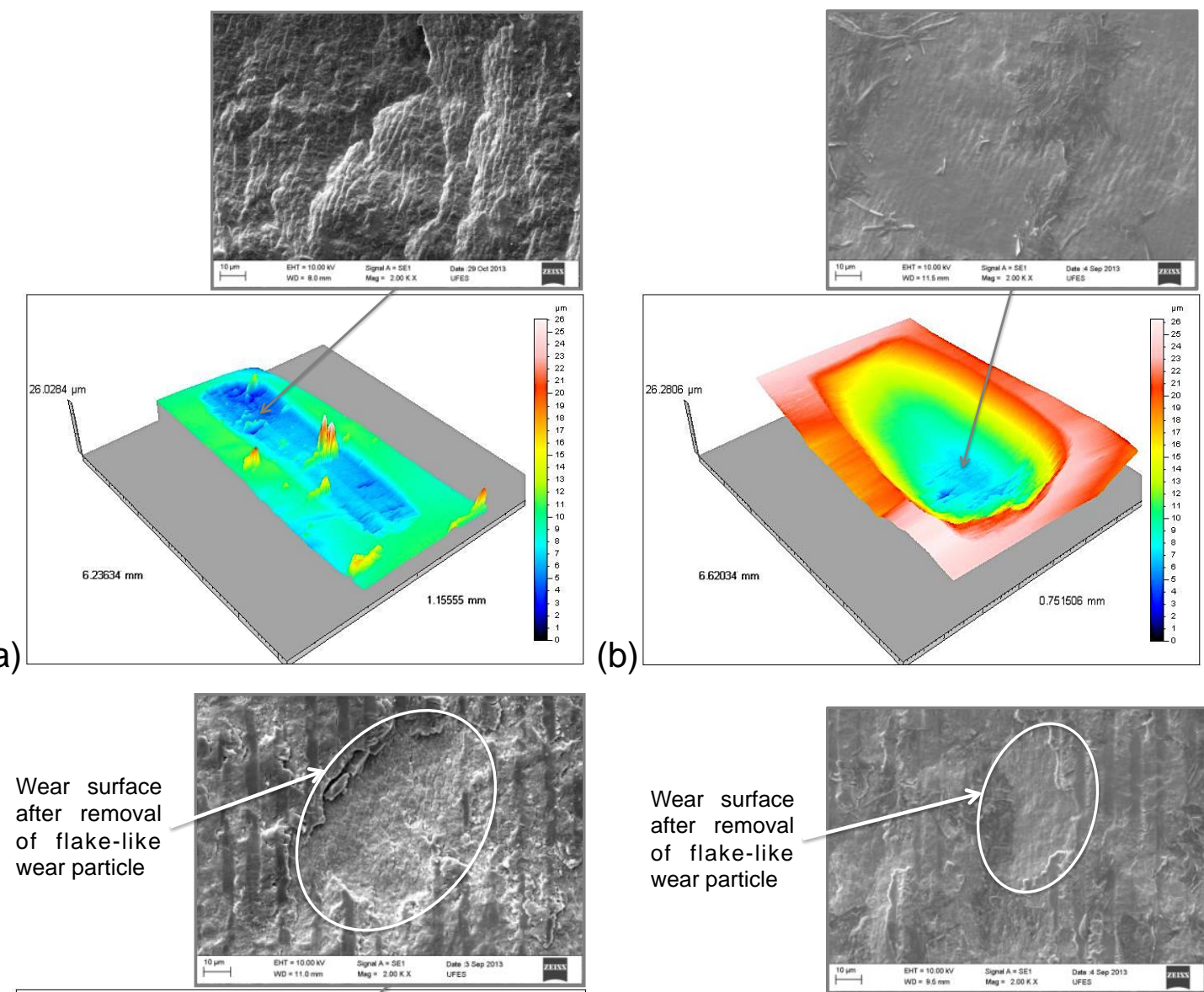

(c)

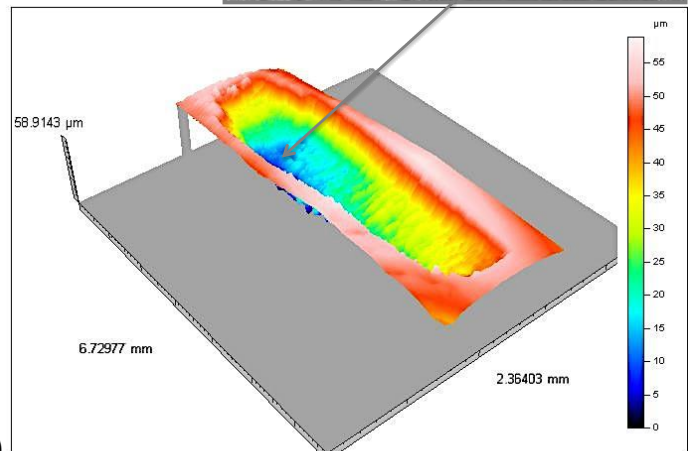

(d)
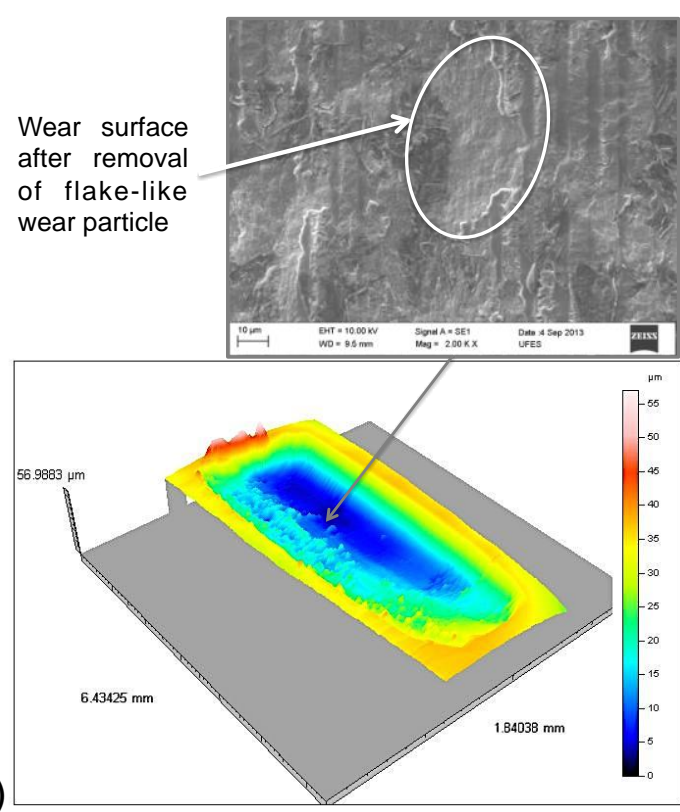

Figure 7. 3D topography and SEM images of the surfaces of the specimens in different conditions: (a) $8 \mathrm{~N}$, dry; (b) $8 \mathrm{~N}$ natural saliva; (c) $16 \mathrm{~N}$, dry; (d) $16 \mathrm{~N}$ natural saliva.

* Technical contribution to the $2^{\text {nd }}$ International Brazilian Conference on Tribology - TriboBR 2014, November $3^{\text {rd }}$ to $5^{\text {th }}$, 2014, Foz do Iguaçu, PR, Brazil. 

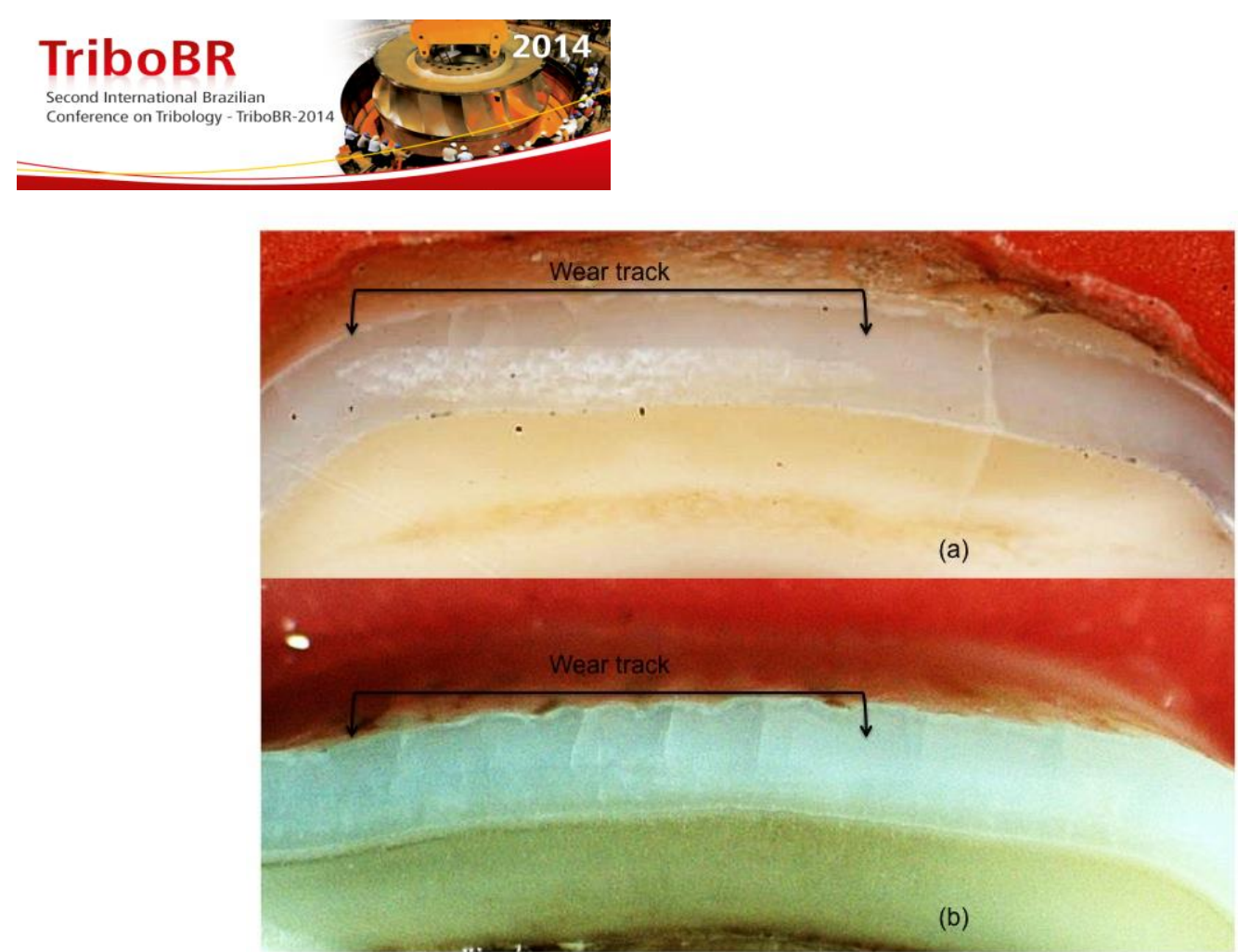

Figure 8. Images from the wear tracks formed in the different conditions: (a) $8 \mathrm{~N}$, dry; (b) $8 \mathrm{~N}$, natural saliva.

Figure 9 shows the values of Sq within the wear track of the specimens. Initially, we observe that the roughness values of the specimens tested under load of $16 \mathrm{~N}$ were higher than those of $8 \mathrm{~N}$. Regarding the effect of lubrication, although the higher wear volume obtained under $8 \mathrm{~N}$ load (Figure 6), the roughness provided by natural saliva lubrication is lower than those measured in the dry condition, which confirms the presence of tribochemical reaction interacting with the mechanical loading. Under a normal load of $16 \mathrm{~N}$, the most severe condition (dry) showed a roughness value 2.5 times greater than those obtained in the lubricated condition.

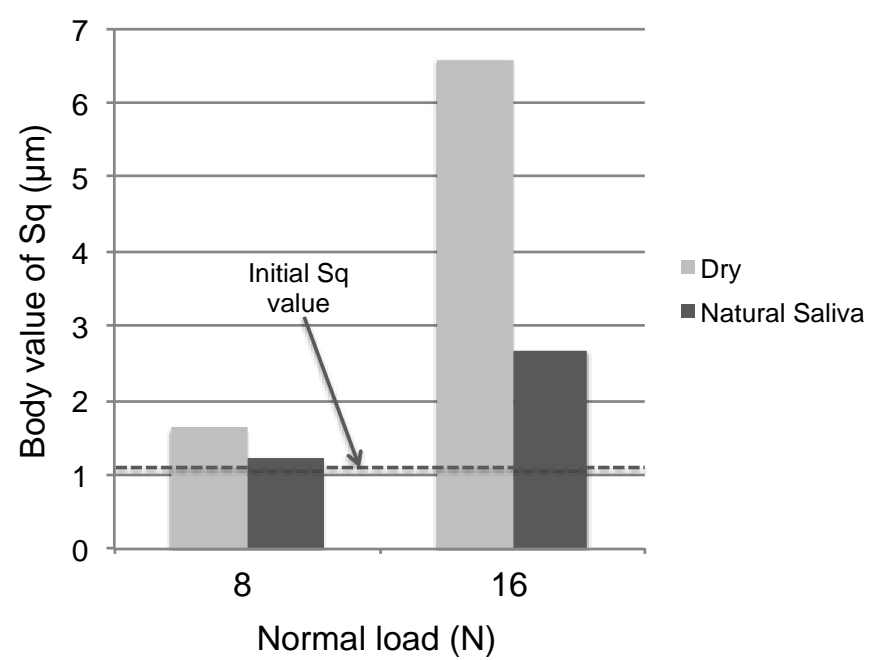

Figure 9. Sq values of worn surfaces of the specimens tested in the different lubrication conditions as a function of the normal load.

\subsection{Friction Behavior}

The friction coefficient values obtained on the stationary part of the friction curve as a function of time, for the three pairs used in the tests are shown in Table 1. 


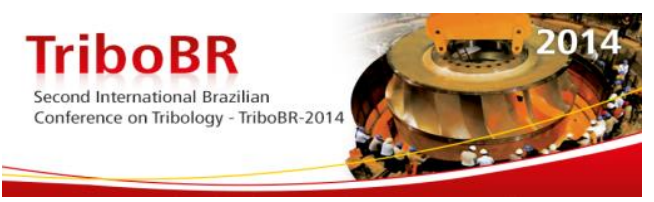

Table 1. Friction coefficient values obtained on the stationary part of the friction curve as a function of time for the different conditions of normal load and lubrication

\begin{tabular}{lccc}
\hline & & \multicolumn{2}{c}{ Normal Load $(\mathrm{N})$} \\
& & $8 \mathrm{~N}$ & $16 \mathrm{~N}$ \\
\hline Lubrication & Dry condition & $0.76 \pm 0.04$ & $0.87 \pm 0.03$ \\
\cline { 2 - 4 } Condition & Natural Saliva & $0.74 \pm 0.01$ & $0.74 \pm 0.08$ \\
\hline
\end{tabular}

Under normal load of $8 \mathrm{~N}$, there is a tendency to lower the friction coefficient in the natural saliva lubricated condition, which can be explained by the presence of tribochemical reactions and slightly less rough surfaces.

Under normal load of $16 \mathrm{~N}$, the high friction coefficient in the dry condition reflects the presence of a rougher and more deteriorated surface by brittle mechanisms. Although there is a systems-dependence of frictional behavior [26], from the point of view of the surface topography, the values found for the three conditions studied (8 $\mathrm{N}$-dry, $8 \mathrm{~N}$ and $16 \mathrm{~N}$-lubricated by natural saliva) were close, indicating a correlation with the values of roughness (Figure 9).

\section{CONCLUSION}

The evolution of the wear of the enamel can be verified by the interrupted tests, the initial removal of interprismatic substance, followed by prisms fragmentation and layered material loss.

Increasing the normal load induced brittle wear mechanisms and promoted greater wear volume, despite lubrication, however, the synergistic action of loading and chemical reactions revealed an important result for the low load condition: the tribochemical wear. The presence of tribochemical wear may be the explanation for the dental wear found in young adults presenting with bruxism and salivary lubrication satisfactory - until then, the absence of saliva seemed to favor the higher wear volume.

The results of the friction coefficient and roughness were found essential to justify the presence of wear mechanisms in the different load conditions and lubrication: tribochemical reactions under $8 \mathrm{~N}$ and natural saliva; brittle fracture with formation of flake-like wear particles under $16 \mathrm{~N}$ (dry and lubricated), which is more severe than the mechanism observed under $8 \mathrm{~N}$ in the dry condition.

\section{Acknowledgments}

The authors would like to thank the Conselho Nacional de Desenvolvimento Científico e Tecnológico - CNPq Brasil for their support to this research.

\section{REFERENCES}

1 Kreulen CM, Van 't Spijker A, Rodriguez JM, Bronkhorst EM, Creugers NH, Bartlett DW. Systematic review of the prevalence of tooth wear in children and adolescents. Caries Res. 2010;44(2): 151-9.

2 Dugmore CR, Rock WP. The prevalence of tooth erosion in 12-year-old children. $\mathrm{Br}$ Dent J. 2004 Mar 13;196(5): 279-82; discussion 3.

* Technical contribution to the $2^{\text {nd }}$ International Brazilian Conference on Tribology - TriboBR 2014, November $3^{\text {rd }}$ to $5^{\text {th }}$, 2014, Foz do Iguaçu, PR, Brazil. 


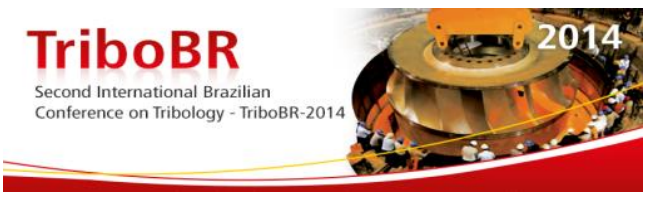

3 Bartlett DW, Fares J, Shirodaria S, Chiu K, Ahmad N, Sherriff M. The association of tooth wear, diet and dietary habits in adults aged 18-30 years old. J Dent. 2011;39(12): 811-816.

4 Van't Spijker A, Rodriguez JM, Kreulen CM, Bronkhorst EM, Bartlett DW, Creugers NH. Prevalence of tooth wear in adults. Int J Prosthodont. 2009 Jan-Feb;22(1): 35-42.

5 Fares J, Shirodaria S, Chiu K, Ahmad N, Sherriff M, Bartlett D. A new index of tooth wear. Reproducibility and application to a sample of 18- to 30-year-old university students. Caries Res. 2009;43(2): 119-25.

6 Grippo JO, Simring M, Coleman TA. Abfraction, abrasion, biocorrosion, and the enigma of noncarious cervical lesions: a 20-year perspective. J Esthet Restor Dent. 2012 Feb;24(1): 10-23.

7 He LH, Swain, MV. Understanding the mechanical behavior of human enamel from its structural and compositional characteristics. J Mech Behav Biomed Mater. 2008; 1(1): 18-29.

8 Jeng $\mathrm{Y}$, Lin $\mathrm{T}$, Hsu $\mathrm{H}$, Chang $\mathrm{H}$, Shieh D. Human enamel rod presents anisotropic nanotribological properties. J Mech Behav Biomed Mater. 2011 May;4(4): 515-22.

9 Kato K. Tribology of ceramics. Wear. 1990; 136(1): 117-133.

10 Hutchings IM. Tribology: friction and wear of engineering materials. 5 ed. London: Arnold; 1999.

$11 \mathrm{Li} \mathrm{H}$, Zhou ZR. Wear behaviour of human teeth in dry and artificial saliva conditions. Wear. 2002;249(10-11):980-984.

12 Eisenburguer M, Addy M. Erosion and attrition of human enamel in vitro. Part I: Interaction effects. J Dent. 2002;30(7-8): 341-347.

13 Sajewicz E. Effect of saliva viscosity on tribological behaviour of tooth enamel. Tribo Int. 2009 Feb;42(2):327-32.

14 Ge J, Cui FZ, Wang XM, Feng HL. Property variations in the prism and the organic sheat within enamel by nanoindentation. Biomaterials. 2005; 26(16): 3333-3339.

15 Sanches RP, Otani C, Damiao AJ, Miyakawa W. AFM characterization of bovine enamel and dentine after acid-etching. Micron. 2009 Jun;40(4): 502-6.

16 Yassen GH, Platt JA, Hara AT. Bovine teeth as substitute for human teeth in dental research: a review of literature. J Oral Sci. 2011 Sep;53(3): 273-82.

$17 \mathrm{Xu} \mathrm{HH}$, Smith DT, Jahanmir S, Romberg E, Kelly JR, Thompson VP, et al. Indentation damage and mechanical properties of human enamel and dentin. J Dent Res. 1998 Mar;77(3): 472-80.

18 Sakar-Deliormanli A, Guden M. Microhardness and fracture toughness of dental materials by indentation method. J Biomed Mater Res B Appl Biomater. 2006 Feb;76(2):257-64.

19 Bechtle S, Habelitz S, Klocke A, Fett T, Schneider GA. The fracture behavior of dental enamel. Biomaterials. 2010; 32(11): 375-384.

20 Regalo SC, Santos CM, Vitti M, Regalo CA, de Vasconcelos PB, Mestriner W, Jr., et al. Evaluation of molar and incisor bite force in indigenous compared with white population in Brazil. Arch Oral Biol. 2008 Mar;53(3): 282-6.

21 Neill DJ, Kydd WL, Nairn RI, Wilson J. Functional loading of the dentition during mastication. J Prosthet Dent. 1989 Aug;62(2): 218-28.

22 Kohyama K, Hatakeyama E, Sasaki T, Dan H, Azuma T, Karita K. Effects of sample hardness on human chewing force: a model study using silicone rubber. Arch Oral Biol. 2004 Oct;49(10): 805-16.

23 Zheng J, Zhou ZR. Friction and wear behavior of human teeth under various wear conditions. Tribo Int. 2007; 40(2): 278-284.

24 Arsecularatne JA, Hoffman M. On the wear mechanism of human dental enamel. J Mech Behav Biomed Mater. 2010 May;3(4):347-56.

25 Adachi K, Kato K, Chen N. Wear map of ceramics. Wear. 1997;203-204 (special issue): 291-301.

26 Blau PJ. The significance and use of the friction coefficient. Tribo Int. 2001; 34 (9): 585591.

* Technical contribution to the $2^{\text {nd }}$ International Brazilian Conference on Tribology - TriboBR 2014, November $3^{\text {rd }}$ to $5^{\text {th }}$, 2014, Foz do Iguaçu, PR, Brazil. 